Subsidiary integration as identity construction and institution building: a political sensemaking approach ${ }^{1}$

\section{Ed Clark}

School of Management

Royal Holloway University of London

Egham

Surrey TW20 0EX

United Kingdom

Tel. +44(0) 1784414007

Fax +44 (0) 1784276100

Email ed.clark@rhul.ac.uk

\section{Mike Geppert*}

School of Management

The University of Surrey

Guildford

Surrey, GU2 7XH

United Kingdom

Tel: +44 (0)1483683100

Email m.geppert@surrey.ac.uk

*Corresponding Author

${ }^{1}$ This paper has been published in Volume 48, Issue 2 in the Journal of Management Studies in 2011 (pp. 395-416) . 


\title{
Subsidiary integration as identity construction and institution building: a political sensemaking approach
}

\begin{abstract}
This paper develops a political sensemaking approach to the post-acquisition integration process, which directs attention to how powerful social actors construct the relationship between multinational corporations (MNCs) and their multiple local contexts. This political, processual and actor-centred perspective explores subsidiary integration as identity construction and institution building. The different characteristics that local and head office managers attribute to the subsidiary establish diverse interests in and political stances towards it and, through actions to resolve these differences, senior decision makers shape the subsidiary's strategic and structural location in the MNC. We illustrate this argumentation with reference to post-socialist acquisitions by Western multinationals, whose contrasting institutional and management experiences put the problem of multiple contexts and subsidiary integration into sharp relief. This approach complements mainstream international business research by attending directly to the neglected processual nature of subsidiary integration and examining different socio-political dynamics resulting from sensemaking and sensegiving interactions between key actors in the MNC.
\end{abstract}

Key words: institution building; multinational corporations; organizational identity; political sensemaking; post-socialism; subsidiary integration 


\section{Introduction}

Over the last two decades of so, international business (IB) research has recorded the tendency for multinational corporations (MNCs) to move from centralized hierarchies towards more differentiated and distributed networks (Ghoshal and Bartlett, 1990; Hedlund, 1986). This observation places issues about the subsidiary - its power, autonomy and local context - at the heart of IB debates. The decentralized view has persuaded some scholars that MNC theory must transcend its focus on structural dimensions to investigate organizational processes and flows (Doz and Prahalad, 1991; Kostova and Roth, 2004). Others argue that the MNC should now be understood as a political coalition, raising questions about how multiple and culturally diverse stakeholders make trade-offs to settle differences (Mudambi and Navarra, 2004). Reconceptualizing the MNC in terms of process and politics is a major theoretical challenge for contemporary IB.

A related problem is to understand how its multiple local contexts shape the modern MNC (Meyer, Mudambi and Narula, 2010). We argue in this paper that local contexts influence the MNC's evolving strategic and structural characteristics through the theoretical juxtaposition of politics, process and action. More specifically, diverse local contexts are expressed in the political actions of powerful actors - like senior managers - who seek to impress their preferred characteristics on the MNC. We elaborate this argument by examining how newly acquired subsidiaries become integrated into MNC frameworks. In the main, the IB literature has approached subsidiary integration as a problem of either structural-strategic fit with the MNC's central needs (cf. Bartlett and Ghoshal, 1989; Roth and Morrison, 1990), or cultural fit and acculturative stress (Birkinshaw et al., 2000; Nahavandi and Malekzadeh, 1988). In their tendency to treat head office and subsidiary management as technically skilled strategic actors capable of resolving the problems that arise from their multiple contexts (Ferner and Quintanilla, 
1998; Kostova, 1999), this mainstream literature has developed around rationalist and functionalist concerns of efficiency and performance.

This paper seeks to contribute to an emergent research strand in IB which offers more politicized explanations of the MNC as being constituted by conflicting relations between head office and subsidiary managements (Birkinshaw and Ridderstråle, 1999; Bouquet and Birkinshaw, 2008; Kristensen and Zeitlin, 2005; Vaara, 2003). We do so by developing a political sensemaking approach to subsidiary integration that draws on organizational identity theory (Dutton and Dukerich, 1991; Gioia and Thomas, 1996) and institutionalist views of the MNC (Kostova, 1999; Kostova and Roth, 2002). The more institutionally distant the pre-acquisition organization is from the MNC, the more likely that the integration process will be characterized by dissensus between local (subsidiary) and head office (corporate) management.

Our theoretical arguments start from the proposition that disputes over the acquired site take place over two main issues: its central characteristics (or identity) and its main organizational practices (or institutions). If head office and subsidiary managers share a similar subsidiary identity and accept internal subsidiary practices as legitimate, the subsidiary can be said to be integrated into the MNC. But the construction of subsidiary identity and institutions is a political accomplishment of powerful actors, who engage in sensemaking to interpret each others' political interests and stances and sensegiving to enforce their own preferences on subsidiary. This argument complements the prevailing rationalist and functionalist logic of IB theory, but focuses on the processual, political and actor-centred nature of MNC-subsidiary relationships, thereby picking up themes central to understanding the modern networked MNC.

The paper makes a number of contributions to the subsidiary integration literature. First, it offers a new way of thinking about subsidiary integration by focusing on processes of identity reconstruction and institution building. Second, in contrast to the mainstream literature, it 
highlights the role of social actors and the political nature of the process. Third, we identify different possible process patterns within the post-acquisition phase and the generative mechanisms that promote their internal dynamics (Van de Ven and Poole, 1995). Overall, this political sensemaking approach to subsidiary integration forges new links between the MNC literature, the theory of organizational identity and neo-institutionalism.

While seeking to contribute to the general theory of subsidiary integration, we illustrate these exploratory arguments with reference to studies of the acquisition - and subsequent restructuring - by Western MNCs of former state owned enterprises (SOEs) in post-socialist economies. We contend that the institutional distance between capitalist and former state socialist contexts makes this literature ideal for developing the contours of a political sensemaking approach.

The paper continues by establishing the basic theoretical ideas of political process, identity construction, institution building and political sensemaking. This is followed by two sections that explain the context of post-socialist transitional sites and elaborate the political sensemaking framework as four ideal-typical scenarios in which head office and post-socialist managers interact over different conceptions of the post-acquisition site. This leads to a discussion of the process implications of the theory and a conclusion that reflects on theoretical and practical implications and offers signposts for future research.

\section{Subsidiary integration: theoretical background}

\section{Process, politics and action}

The political sensemaking approach offers an alternative way of thinking about subsidiary integration by conceptualizing it as a process of identity construction and institution building. In doing so, it presents a form of theoretical argument that is sensitive to the emergent 
characteristics of the modern MNC network and promotes a view of MNC-subsidiary relations as processual, political and actor-centred.

The purpose of studying subsidiary integration as process is to identify the main sequences of events and explain why they evolve over time in a particular way and with particular outcomes (Abbott, 1990; Van de Ven and Poole, 1995). From this methodological position, the MNC is conceptualized as the ongoing social construction of dispersed social actors applying different 'contextual rationalities' to influence the strategic meaning of the subsidiary (Geppert et al., 2003). Seeing subsidiary integration as a process of confronting and resolving conflicts over the nature of the acquisition contrasts with mainstream approaches that often rely on assumptions of a strategically omniscient head office (Kristensen and Zeitlin, 2001) or passive/rational-strategic subsidiary managers (Geppert, 2003). To achieve their political interests, social actors draw on a variety of power sources, some structural but also informal and emergent forms that result from particular combinations of resources, expertise and knowledge (Birkinshaw et al., 2000; Clegg et al., 2006; Mudambi and Navarra, 2004).

\section{Identity construction and institution building}

From our perspective, post-acquisition integration into an existing MNC, then, involves more than the technical resolution of institutional or cultural pressures, the influence of an efficiency imperative or the application of strategic rationality. In fact, it takes place through the interactions of powerful agents, whose contextual rationalities are reflected in the meanings they attribute to and the interests they have in the emergent subsidiary (Geppert et al., 2003; Kristensen and Zeitlin, 2005; Vaara, 2003). The political sensemaking approach examines how key actors' actions try to realize these identity and institutional preferences. 
Subsidiary identity refers to those central, distinctive and relatively enduring features that different stakeholders attribute to the acquired site (Albert and Whetten, 1985) and integration involves efforts to realign the site's identity with the MNC. In principle, there may be as many identities as the subsidiary has coherent stakeholder groups (cf. Pratt and Foreman, 2000; Scott and Lane, 2000), but for analytical purposes we limit our attention those held by central members of the 'acquisition management team' (AMT); that is, those 'head office' and 'local managers' responsible for managing the integration process (Birkinshaw et al., 2000). We examine subsidiary integration by inferring their identities from typified characteristics, which ensures a theoretical focus on their interpretive role in identity reconstruction while staying aloof from the concrete actions of particular individuals (Schütz, 1972; Watkins, 1952). Concentrating on these two actor types and their typified subsidiary identities allows us to focus on the essence of our argument, but we do not underestimate the empirical role of other stakeholders, such as middle managers, non-managerial employees and host government agents; indeed, our detailed arguments reveal that such stakeholders are always directly or indirectly implicated in integration processes.

Head office managers appointed by the MNC to the AMT are likely to attribute a subsidiary identity based on their 'external' knowledge of the pre-acquisition organization and their understanding of the subsidiary's initial strategic assignment. On the other hand, local managers' subsidiary identity will have emerged through pre-acquisition experiences that bind them into a distinctive community, whose values reflect their common local context (Vaara, 2003). When identity differences between the two groups are successfully addressed, integration efforts are likely to culminate in a common identity and a shared understanding of the subsidiary, its problems and its prospects (cf. Dutton and Dukerich, 1991; Gioia and Thomas, 1996). 
Post-acquisition also raises issues about the subsidiary's 'proper' organizational practices (Vaara, 2003). Since the acquired site enters the MNC with its own legitimately established practices, local actors may find it difficult to accept MNC know-how and practices as their own; similarly, the MNC has its own institutionalized strategic and operational practices developed through years of international experience (Ferner and Quintanilla, 1998; Kostova and Zaheer, 1999; Roth and Morrison, 1990). Like Kostova (1999), we treat the transfer, assimilation or evolution of subsidiary practices as a process of institutionalization that restructures the acquired site. Subsidiary integration therefore involves (re)building institutions through processes of acquisition, implementation and internalization that legitimize organizational practices. Since institutional development threatens the inherited pattern of legitimacy and resources, it inevitably raises issues of power (Easterby-Smith et al., 2008).

In reality, identity construction and institution rebuilding are interrelated processes. Subsidiary identity is the common source of the values that permeate and legitimize organizational practices; in this respect, identity and institutions tend to be mutually reinforcing. Until identity and institutional alignment has taken place, the acquired organization remains a 'construction' site in transition, with the potential for conflict over the meaning of the subsidiary and the legitimacy of its structures and practices.

\section{Political Sensemaking}

Where the MNC and its new acquisition are characterized by institutional distance and distinctive contextual rationalities, there is unlikely to be much overlap in the identities ascribed to the subsidiary. Through the perceptual lenses of their respective subsidiary identities, head office members of the AMT are likely to see local managers as in need of corporate socialization, while local managers may treat head office agents as outsiders to, even invaders or occupiers of, their organization (Haspeslagh and Jemison, 1991). But subsidiary identity is more than a cognitive 
concept influencing perceptions of the acquisition; by providing their preferred normative vision of the subsidiary, it also defines the actors' interests in rebuilding the transitional site, likely political stances towards it and subsequent behavioural responses to integration (cf. Clemens and Cook, 1999).

The language of sensemaking succinctly captures the politics of identity construction (Gioia and Chittipeddi, 1991). In a sensemaking process, social actors perceive, interpret and evaluate each other's conduct as it impacts on their understanding of the subsidiary; in a sensegiving process, actors use power and other resources to enact their subsidiary identity, to respond meaningfully to and thereby influence the behaviour of others. One actor's sensegiving prompts the other's sensemaking responses, in turn leading to the latter's sensegiving acts and the emerging political process of integration (see Figure 1).

Figure 1 about here

While politically astute local managers might take actions to pre-empt their new owner's control over the subsidiary, the first post-acquisition acts are likely to be made by head office management. Head office managers can project their subsidiary identity through symbolic acts, such as defining its strategic role in terms of the MNC's traditional values and attempting to transfer organizational practices like quality assurance (Birkinshaw and Hood, 1998; Birkinshaw and Morrison, 1995; Ghoshal and Bartlett, 1988; Jarillo and Martínez, 1990). In these sensegiving acts, head office managers try to influence the subsidiary's identity and institutions by embodying their preferred meanings within the acquired site (Hatch and Schultz, 2002).

The political process is given its initial shape by how local managers perceive, interpret and evaluate head office identity projections. Where head office action leaves the acquired site 
relatively unchanged, local managers are likely to construe the projected subsidiary image as consonant with their own subsidiary identity, leading to the reproduction of their local identity and institutions. However, when post-acquisition acts challenge local practices, provoke hostility (Hirsch, 1986) and disrupt routines, local managers will construe head office managers' subsidiary identity as discrepant with their own (Dutton and Dukerich, 1991) and construct an appropriate sensegiving response (Vaara, 2003; Weick, 1995). This may take the form of leaving the subsidiary (Hambrick and Cannella, 1993); however, non-exit sensegiving acts - such as resistance - can force head office managers into a further round of sensemaking and sensegiving, thereby politicizing integration (Hennart and Larimo, 1998). In this way, sensemaking interactions construct sequences of events with identity and institution building consequences.

Local managers' responses are likely to be tempered by the head office managers' political stance. When sensegiving acts are perceived as coercive or dominating, for example, local managers may adopt defensive tactics that vary from opposition to ceremonial acceptance, in which transferred practices fall short of internalization (Kostova, 1999; Kostova and Roth, 2002). A negotiatory stance may evoke more willing adoption of head office's conception of the subsidiary and its practices. By the same token, a locally hostile stance may provoke retaliatory sensegiving responses from head office, with implications for their next integration attempts. In short, the dynamics of subsidiary integration take shape as local and head office managers address their political differences; in doing so, they negotiate a sense of organizational order, construct an organizational impasse or create conditions for conflict or change.

\section{The Post-Socialist Context and Subsidiary Identities}

We explore the processual implications of these arguments within the specific context of European post-socialist acquisitions. While there were important variations between Central and 
Eastern European communist societies (Jeffries, 1990), our arguments recognize that state socialism across the region shared institutional principles and practices that were significantly different from prevailing market-economic forms.

The transformation of state-owned enterprises called for the radical reconstruction of identity and practices, because, as products of the command economy, they were structurally, culturally and managerially maladapted to the global market economy (Newman, 2000; Soulsby and Clark, 2007). Doing nothing ('no restructuring') was widely recognized as a recipe for stagnation and failure; undertaking shallow or 'defensive restructuring', involving short-term changes to contain costs, would at best have kept the enterprise afloat. Most transition researchers agreed that foreign direct investment (FDI) from Western MNCs was the most likely source of higher long-term performance through deep or 'strategic restructuring' that built new institutional practices with higher capabilities (Meyer, 2000; Meyer and Lieb-Dóczy, 2003; Uhlenbruck et al., 2003). These three positions are broadly indicative of differing degrees of (re)institutionalisation of subsidiary practices.

By restricting focus to the institutional conditions of post-socialism, we can hold constant some of the complexities of international management research. But more importantly, such postsocialist sites offer a unique institutional setting (Peng, 2003), because they are characterized by values and institutions very different from their Western acquirers. This application of the logic of theoretical sampling (Glaser and Strauss, 1967) provides the conditions for 'polar' or 'extreme' cases of subsidiary integration (Yin, 2003), because the empirical differences between MNC and acquisition are likely to render central theoretical issues of identity and institutional building more 'transparently observable' (Eisenhardt, 1989; cf. Newman, 2000). 
We draw respectively on the international business and post-socialist literatures to portray typified social actors with characteristic subsidiary identities and the power to influence the integration process. Such constructs are not intended to capture the full empirical range and richness of subsidiary identities; however, each comprises characteristics that are conceptually consistent with known configurations of contextual and organizational factors. In what follows, we refer only tangentially to the likely institutional, industry sector and national factors that may shape these ideal-type patterns, because our theoretical interests lie in the consequences of the identity types for differentiating actor interests in and political stances towards subsidiary integration.

\section{Head Office Subsidiary Identities}

We adapt two established IB constructs to classify the head office managers' subsidiary identity: the MNC's strategic mindset (Gupta and Govindarajan, 2002; Perlmutter, 1969) and its strategic mandate for the subsidiary (Birkinshaw and Hood, 1998; Ghoshal and Bartlett, 1988). The head office's strategic mindset - varying between ethnocentrism and polycentrism - is shaped by the MNC's home institutional and global industrial sector environments (Ferner and Quintanilla, 1998; Kostova and Zaheer, 1999), corporate legacies (Bartlett and Ghoshal, 1989) and its accumulated experience in cross-border acquisitions (Rosenzweig and Nohria, 1994). In addition to these factors, the head office's foreseen strategic mandate is likely to be influenced by the MNC's specific acquisition experiences of similar firms and any relevant information it may have acquired, which shape its views about local management and workforce capabilities.

Using this logic, we distinguish between two patterns of head office subsidiary identity: 'strategic dependant' and 'strategic partner'. 
Subsidiary as a strategic dependant. When an MNC acts with an ethnocentric mindset (Kostova and Zaheer, 1995; Perlmutter, 1969) and assigns a non-creative strategic mandate to the new acquisition, such as miniature replica or rationalized manufacturer (White and Poynter, 1984), its head office managers are likely to see the subsidiary as a strategic dependant (see Table I). In the early post-socialist years, MNC managers tended to make prior attributions based on generalized stereotypes of the financially weak and technologically backward post-socialist site with ‘worthless' competences (Geppert and Merkens, 1999) and low managerial confidence (Czeglédy, 1996). Given this perception, head office managers were hesitant to share information and grant discretion and responsibility, so they transferred standardized Western knowledge unilaterally to exploit known capabilities (Cyr and Schneider, 1996; Geppert et al., 2003).

Since the MNC sees the subsidiary as a strategic instrument and its commitment is expedient, it is in the head office managers' interests to apply short-term financial performance criteria (Lewin et al., 1999) and hold local management to account by enforcing centralized control (Ferner and Quintanilla, 1998; Jarillo and Martínez, 1990). Other things being equal, head office managers attributing a strategic dependant identity will adopt a political stance of exercising direct control through unilateralism or domination.

\section{Table I about here}

Subsidiary as a strategic partner. Holding a cosmopolitan or polycentric mindset (Gupta and Govindarajan, 2002; Perlmutter, 1969) and assigning creative mandates like product specialism and strategic independence (Birkinshaw, 1996; White and Poynter, 1984) indicate that head office management sees the subsidiary as a strategic partner. In attributing this identity, head office managers show confidence that local management, the workforce and the local institutions can 
support technological innovation and managerial discretion. In these circumstances, head office managers are comfortable with sharing knowledge, learning about local ways and creating opportunities for local strategic initiatives.

Anticipating long-term collaboration, head office management has a direct interest in building onsite institutions that develop local capabilities (Ferner and Quintanilla, 1998; Lewin et al., 1999). Therefore, we would anticipate head office support through normative control exercised in lateral relationships (Ghoshal and Bartlett, 1988; Rosenzweig and Nohria, 1994). Other things being equal, head office managers holding a strategic partner identity adopt a political stance of negotiating on-site changes with the local management.

\section{Post-Socialist Subsidiary Identities}

From the transition-economic literature, we infer that post-socialist subsidiary identity is likely to be associated with two interrelated conditions arising from managerial experiences of the command economy: the extent of local embeddedness and openness to new ideas (Clark and Soulsby, 1999; Newman, 2000; Peng, 2003).

First, being locally embedded was a normal consequence of the command economy, which strongly rewarded managers for loyalty to the organization, its work force and the local community (Edwards and Lawrence, 2002) and encouraged close ties with economic partners in the same industrial sector (Stark, 1996). On the other hand, many post-socialist managers rapidly realized that their future careers depended not only on their local strengths but also on their ability to detach themselves from these local constraints (Nooteboom, 2000) and grasp the opportunities offered by foreign ideas and practices. 
Second, post-socialist managers held a range of attitudes towards new ideas. In order to survive in a shortage economy, SOE management had drawn on engineering traditions and cultivated practices of self-reliance (Kornai, 1980). Older managers in particular had forged their careers through commitments to communist organs and built their management on traditional ways, making them resistant to new ideas (Newman, 2000; Soulsby and Clark, 1996). However, others had worked in SOEs with innovative reputations, cooperated with external companies and were aware that their organizations could only survive by being open to ideas beyond their experience. This latter pattern was particularly true of younger managers, who rose to senior levels after the collapse of communism.

Together, these two dimensions point towards the capacity of local managers to absorb ideas and practices from the MNC (cf. Cohen and Levinthal, 1990) and allow us to differentiate two patterns of post-socialist subsidiary identity: the 'local patriot' and the 'cosmopolitan player' (see Table II).

Table II about here

Subsidiary as local patriot. Where local management is deeply committed to its enterprise, workforce, socio-economic networks and the values of self-reliance, it typically attributes a 'local patriot' identity to the subsidiary. This identity is likely to be held by ideologically committed older managers from former strategic SOEs and in the early post-socialist period. Because of its roots in local traditions, this identity exacerbates the impact of institutional distance between the subsidiary and head office (Czeglédy, 1996). Furthermore, it reflects a belief in the enterprise's ability to survive by adapting local know-how and a scepticism towards foreign business values and knowledge (Peng, 2003; Simon and Davies, 1996). Such an identity may be especially 
pronounced in former SOEs forced by the government to find a foreign parent (Brouthers and Bamossy, 1997).

Since managers holding this identity assess integration efforts in terms of their local consequences, their immediate interests are to maintain strategic autonomy on the basis of traditional practices. In the early 1990s, many local managers saw MNC actions as colonial (Simon and Davies, 1996), intrusive (Child and Czeglédy, 1996) or culturally coercive (Czeglédy, 1996), contrasting the 'arrogance' of Western knowledge (Clark, 2008) with their own autarkic traditions and anxious about downsizing practices that clashed with duties of employee and community care (Brouthers and Bamossy, 1997; Pavlínek 2002). These circumstances can result in the deliberate withholding of local information and the manipulation of MNC-originated knowledge (Michailova and Husted, 2003). Other things being equal, a local patriot identity is associated with a defensive political stance, though its manifestations may vary between active opposition to reluctant acceptance.

Subsidiary as cosmopolitan player. Being steeped in command-economic experiences, managers projecting a cosmopolitan subsidiary identity accept the need to extend beyond traditional production values by participating in global networks and reaching outwards for new marketeconomic know-how (Stark, 1996; cf. Nooteboom, 2000). Indeed, SOEs in some sectors (e.g. foreign trade) in some countries (e.g. Hungary) had progressive reputations and direct market experiences, which were conducive to a more open outlook (Clark and Soulsby, 1999). Openness to foreign ideas may also reflect a calculative shift in 'loyalty' by former senior managers recognizing the need for professional rehabilitation.

Whatever the motives, local managers holding a cosmopolitan identity have interests in facilitating strategic cooperation with an MNC that brings much needed market-economic know- 
how and practices (Meyer and Lieb-Dóczy, 2003; Soulsby and Clark, 2007). By seeing the subsidiary as an opportunity to learn new things, the cosmopolitan identity signals a willingness to commit to the MNC. Other things being equal, such post-socialist managers adopt an accepting political stance conducive to higher levels of institution building, though in practice this may vary from voluntary internalization to ceremonial implementation of transferred knowledge (Geppert and Merkens, 1999; Meyer and Lieb-Dóczy, 2003; cf. Kostova, 1999).

\section{Political Sensemaking and Post-Socialist Subsidiaries}

As local and head office managers interact to realize their respective subsidiary identities in the transitional site, their political sensemaking generates the dynamics of subsidiary integration. The different combinations of subsidiary identity construct four initial post-acquisition scenarios, which are likely to generate distinctive process patterns over time (see Figure 2). As head office managers begin to reveal their preferred subsidiary characteristics - for example, by transferring knowledge, changing in the scale or composition of the work force or introducing new managers - they are likely to provoke the first critical post-acquisition event, which interrupts the local management routines. We illustrate the arguments through careful reinterpretation of research findings from empirically rich case studies of Western acquisitions of former SOEs, such as VW Group's integration of Škoda.

Figure 2 about here

\section{Scenario 1: Consensual sensemaking}

This first scenario brings together head office and local managers, holding respectively strategic partner and cosmopolitan player subsidiary identities. These identities, their associated interests and political stances are essentially compatible and therefore conducive to negotiation of on-site 
institutions. Local managers are likely to perceive the actions of a strategic partner as indicative of cultural sensitivity and a long-term commitment to reconcile concrete differences, because their cosmopolitan openness dispels early suspicions and favours new practices (Meyer and LiebDóczy, 2003). Moreover, by encouraging local managers to participate in transnational projects and networks, head office actions may cultivate mutual respect for differences and reciprocal trust (Cyr and Schneider, 1996). As local managers become more involved in the MNC through consensual sensemaking, their own ideas receive corporate airing and greater legitimacy.

The VW Group's initial post-acquisition interactions with Škoda offer a good example. Driven by the Chief Executive Officer (CEO), Carl Hahn, VW management sought to enact its international strategy of 'equality among production sites', in which VW invested in the Škoda brand, its core functions (including research and development), engineering values and local supplier network (Dörr and Kessel, 2002; Pavlínek, 2008). This resonated well with the 'productionist' identity of local players with interests in strategic upgrading and concern for employees (Janovskaia, 2008).

\section{Scenario 2: Defensive sensemaking}

Interpreting head office managers' strategic partner projections through a local patriot lens reveals an initial incompatibility between these identities, their related interests and political stances. Head office managers projecting a strategic partner identity seek to build institutions in the subsidiary by encouraging local members' participation in the project. However, since local patriot managers may construe these intentions as discrepant, possibly provocative, sensemaking exchanges may be shaped by local defensiveness. For example, the dependency and risk avoidance attitudes of locally embedded managers might limit their ability or willingness to get involved in decentralized projects. Defensive sensemaking can politicize the acquired site and lead to reluctant implementation of transferred practices and limit levels of institution building (Child and Markóczy, 1993; Kostova, 1999). 
In this precarious status quo, how the process of subsidiary integration unfolds over time depends on how head office managers in turn construe and respond to the local managers' defensive sensegiving. A priori, there are two possible general dynamics. The first dynamic (see arrow 2a) is an adaptive process enabled by head office managers who construe local patriot defensiveness as an 'insignificant' discrepancy and persevere with further displays of commitment. Over time, local managers may accept this as evidence of the MNC's allegiance to the subsidiary and its capabilities, 'converting' them to a more cosmopolitan posture and permitting more consensual sensemaking (scenario 1). In their study of the integration of Opel's Polish subsidiary, DoboszBourne and Jankowicz (2006) show how, by persisting with an 'open-minded approach' in the face of local defensiveness, Western managers negotiated an agreed set of meanings with local managers and employees over new Japanese working practices.

Dynamic $2 \mathrm{~b}$ describes a non-adaptive shift that threatens the integration process. In this case, local managers continue to construe head office management actions as discrepant with their own subsidiary identity and increase oppositional efforts, for example, by mobilizing the support of their workforce or local economic networks (Pavlínek, 2002). If sensemaking continues to be contested over time, head office managers are likely to lower their expectations of the subsidiary, resorting to strategic dependence. In Hurt and Hurt's (2005) analysis of French retail MNCs' integration of Polish supermarkets, continued reassertions of local defensiveness deteriorated to more confrontational patterns of interaction (see scenario 4).

\section{Scenario 3: Dominated sensemaking}

The third scenario is constructed from the combination of strategic dependant and cosmopolitan identities. Like scenario 2, these are likely to find expression in contested interests in and opposing political stances towards the transitional site, though this time sensemaking takes shape 
around head office managers' attempts to impose cost-reducing and standardizing practices (Meyer and Lieb-Dóczy, 2003; cf. Taggart and Hood, 1999). Even through a cosmopolitan lens, post-socialist managers may initially accept unilateral assertions as a requirement for overcoming historical impediments to development. However, over time, they are likely to perceive head office managers as insensitive to local capabilities (Child and Czeglédy, 1996), because they undermine the legitimacy of local professional identities such as engineers (Geppert, 2003) or local networks and practices (Pavlínek, 2008). If post-socialist managers accept the dependent role - for example, to enhance their career opportunities within the MNC - they may compromise their local reputations; if they reject it and seek to realize their cosmopolitan claims by asserting the very autonomy that head office withholds - e.g. by acting secretly to increase the scope of their mandate - they are likely to find themselves in direct conflict with head office (Birkinshaw and Ridderstråle, 1999; Bouquet and Birkinshaw, 2008). Where this state of dominated sensemaking persists, it may politicize on-site institution building, leading to superficial implementation and shallow restructuring.

In the longer term, scenario 3 is conducive to two dynamics. Dynamic $3 b$ is non-adaptive, occurring when post-socialist managers, frustrated by their lack of autonomy, lose confidence in head office management and seek local support for their ambitions (Pavlínek, 2002). This shift towards a more localized identity may also happen if open-minded managers resign (cf. Hambrick and Cannella, 1993) to be replaced by those with a local patriot identity. Efforts to enforce local compliance by increasing expatriate presence in the AMT may simply displace the locus of contestation to internal (e.g. trade unions) or external (e.g. government) stakeholders.

The Škoda case again offers illustrative evidence. The early 1990s' global downturn in the automotive sector prompted VW to appoint a more financially oriented CEO, Ferdinand Piëch. He unilaterally reduced the promised investment in Škoda (Becker, 1997) and imposed policies of 
platform-sharing, which transferred important R\&D capabilities to German plants, and tandem management, which increased VW 'surveillance' of Czech managers. This pattern of dominated sensemaking shifted the case towards scenario 3 and, being discrepant with local managers' expectations, created shock (Pavlínek, 2008) and a crisis of trust that politicized the project (Dörr and Kessel, 2002). The outcome was a further non-adaptive shift to scenario 4, as Škoda managers and employees took an actively defensive stance.

On the other hand, when head office managers adjust their subsidiary identity to make sense of local managers' cosmopolitan responses, an adaptive process (3a) may evolve. Thus, local manoeuvrings to enhance the subsidiary's strategic mandate may persuade head office managers to offer more than a local implementer role and support investment that better suits the site's endemic capabilities (Birkinshaw and Morrison 1995; Bouquet and Birkinshaw, 2008). Having provoked local antipathy, VW's head office managers worked hard during 1994 to re-establish collaborative relations. Piëch apologised for his unilateralism and a compromise was negotiated over cost-cutting policies that gave Škoda management more autonomy within VW's structures (Dörr and Kessel, 2002). Prompt VW action and Škoda's acceptance of VW's softer political stance are partly captured in the adaptive process $3 \mathrm{a}$.

\section{Scenario 4: Oppositional sensemaking}

The final scenario expresses a juxtaposition of interests and political stances - a confrontation of models (Hurt and Hurt, 2005) - that, over time, may challenge the position of the acquisition within the MNC. A strategic dependant identity may be enacted through unilateral decisions to close plants and downsize the workforce, play expedient global games (Morgan and Kristensen, 2006) and promote new professional elites (e.g. marketing and finance) into powerful subsidiary positions. Post-socialist managers assigning local patriot meanings are likely to interpret these actions as highly discrepant, a threat to their social values and professional autonomy, a constraint 
on expressing local capabilities and a downgrading of traditional occupational identities like engineers (Geppert, 2003). In turn, this may reinforce suspicions of MNC intentions and, at the extreme, post-socialist managers may mobilize local support to oppose head office intentions (Child and Czeglédy, 1996; Simon and Davies, 1996). Even ambitious local managers may be dissuaded from compliance with imposed strategic dependence by local threats to their reputation and legitimacy (Child and Markóczy, 1993).

Persistent acts of defensive non-compliance or resistance are likely to confirm head office managers' preconceptions of post-socialist management incompetence and reinforce their initial subsidiary identity around low expectations, expedient commitment and hierarchical control. While it is possible for head office managers to retrieve the situation from early confrontation (Hurt and Hurt, 2005; Pavlínek, 2008), where they try to enforce local compliance by, for example, expatriate postings, local defensiveness may simply be displaced to the lower echelons of management, the workforce or external actors. Overall, this process of oppositional sensemaking is likely to produce a spiral of mutual mistrust and misunderstanding, with each protagonist strengthening its initial identity. Where the acquired site enters an institutional crisis and becomes a 'battlefield' (Kristensen and Zeitlin, 2001) over identity, the MNC may choose to exit the situation by disposing of the troublesome asset. Even if dissent can be contained, scenario 4 may result at best in ceremonial implementation and low levels of institution building.

\section{Process patterns in subsidiary integration}

The scenarios bring together powerful social actors whose subsidiary identities define their interests in and political stances towards the integration of post socialist acquisitions into Western MNCs. As head office and local managers marshal their power resources to realize their 
subsidiary identities, they construct process patterns with differing integration outcomes. In this section, we consider the general characteristics of four main process patterns (see Table III).

\section{Accumulating process}

The actor characteristics of scenario 1 are associated with an integration process that is essentially positive for both parties. The congruent political stances and interests of strategic partner and cosmopolitan identities are conducive to consensual sensemaking and commitments that minimize the effects of institutional distance. This stable accumulating process is generated through consonant perceptions of identity that reproduce routine sensemaking and - unless external events intercede, as in the VW-Škoda case - moves towards a shared subsidiary identity, deep institutionalization of new practices (strategic restructuring) and subsidiary autonomy with devolved creative mandates.

Table III about here

\section{Adaptive process}

Both scenarios 2 and 3 bring together actor characteristics that can generate a process that deepens integration. Initially incongruent identities and their political stances lead to contested sensemaking, whether this is shaped by power to defend the position of local managers or to enforce the will of head office managers. Adaptive processes are prompted when a 'blocking' social actor resolves identity discrepancies by adopting a more conciliatory political stance that narrows the expression of differences. The initial status quo that results at best in shallow restructuring and minimal institution building shifts towards a resolution with increasingly shared identity, deeper institution building and greater subsidiary autonomy.

\section{Non-adaptive process}


Scenarios 2 and 3 can also generate growing resistance to subsidiary integration, when the political stances linked to incongruent identities result in a spiral of increasingly contested sensemaking. In the case of non-adaptive processes, initial rounds of disputation over subsidiary identity are reinforced by the exercise of power that turns the initially open-minded party towards a more antagonistic political stance. In turn, this promotes more entrenched positions of domination and defensiveness and aggravates the expression of differences. From a precarious initial balance that is conducive to shallow restructuring and ceremonial institution building, nonadaptive processes increase instability, resistance to institution building and strategic dependence.

\section{Deteriorating process}

When identities are or become contradictory, subsidiary integration is likely to be drawn into a deteriorating process. As conflicting interests and political stances become manifest, the two parties perceive persistent discrepancies that drive oppositional sensemaking, which over time is likely to entrench the political process and create a sense of crisis. At an extreme, this process becomes antagonistic and the only processual resolution is the closure or offloading of the acquired site, signalling exit. Where oppositional sensemaking endures, integration is likely to fail since new practices are not institutionalized, leading to little or no restructuring and a lack of strategic direction.

\section{Concluding Comments}

The IB literature has tended to view the MNC as comprising economically rational actors applying strategic logic to align the MNC and its subsidiaries with its multiple contexts (Kristensen and Zeitlin, 2001). One consequence of this perspective is to distract attention from processes of intra-corporate power and contestation, which, although an emergent interest in the literature, need more explicit theoretical development. In responding to the current state of the 
literature, our paper builds links between often unconnected debates on change in IB and organization theory. Critical IB scholars have stressed the need to go beyond the study of change in MNCs that focuses on structural questions of efficient strategic, structural or cultural fit (Kostova et al., 2008; Vaara, 2000). By seeing MNCs as 'products of a continuous process of sensemaking, enactment and negotiated interactions' (Kostova et al., 2008, p. 1002), recent scholars have sought to bridge issues in IB and current organization theory and have called for studies of the 'politics of sensemaking' to get deeper insights in organizational 'crisis and change' (Maitlis and Sonenshein, 2010, pp. 570-72). These processual questions are at the heart of this paper, which theorizes subsidiary integration into MNC frameworks as processes of identity reconstruction and institution building, politically accomplished through sensemaking involving local and head office AMT managers.

Theorizing subsidiary integration as identity (re)construction makes several theoretical contributions to the MNC literature. First, subsidiary identities, formed through experiences within distinctive local contexts, provides a culturally rich concept that allows us to understand how local context impacts upon MNC management processes such as post-acquisition integration through social action. Second, subsidiary identities are directly associated with the interests that their holders have in the subsidiary and are reflected in their political stance towards it. Seeing the MNC as a politicized arena offers an empirically fertile way of examining post-acquisition processes and international management in general.

Third, this political sensemaking approach directly attends to the processual nature of subsidiary integration and our theoretical arguments have identified different dynamic patterns that result from sensemaking interactions between key social actors. This complements the more mainstream structuralist studies which investigate post-acquisition integration through testing relationships between measurable variables at a single point in time. Fourth, and perhaps most 
importantly, identity construction points to the role of perceptual discrepancies, sensemaking and sensegiving in propelling the integration process over time. In theorizing beyond generalizing assumptions of rationality or efficiency imperative, we can get inside the black box of MNC process to identify internal dynamic motors (Van de Ven and Poole, 1995). Overall, the political sensemaking approach to subsidiary integration adds new insights to the IB literature that has been predominantly defined by rationalist, structuralist and functionalist theorizing, and offers the potential to organize the growing number of studies of MNC politics. At the same time, this first major attempt to adapt concepts of organizational identity construction to the field of IB, in which plural, distributed settings are normal organizational characteristics, provides an exploratory glimpse into the potential gains from applying this important strand of organization theory to MNCs.

The political sensemaking perspective has some important implications for practitioners at both head office and subsidiary levels. First, in general, managers within the strategic AMT need to understand the subtle role played by identities and contextual rationalities in the evolution of the subsidiary. Instead of locating the source of contestation in personality clashes, interpersonal misunderstandings or forms of negative stereotyping, contextually sensitive AMT managers who genuinely comprehend how and why different groups of actors make sense of their actions have a better chance to steer the political process towards their desired strategic outcomes. Paying attention to political sensemaking may be especially important when head office is concerned to overcome resistance and integrate the subsidiary based on consensus (scenario 2, above). Given the variety of contextually legitimate sources of local contestation, consensual sensemaking may be a more difficult trick to pull off than first appears. Second, our arguments demonstrate that enforcing unilateral decisions in a push for quick integration can have unexpected results if head office has misunderstood local identities. Strategic impositions may result in ceremonial adoptions of practices or, worse, in increasing politicization that affects integration in the longer 
term. Sensitivity training for AMT members may improve awareness of sensemaking issues and offering special events for exchanging views on subsidiary identity and internal practices may provide useful instruments for managing integration.

In taking the first steps towards a political sensemaking approach to MNC-subsidiary relations, we have made restrictive assumptions that need to be loosened in future research. First, we have limited our attention to two main actors - head office and local members of the AMT. IB needs to study a wider range of actors, encompassing external players (such as governments, customers, suppliers and shareholders) and other internal actors (such as employees and professionals). Already, existing studies indicate that the state (Brouthers and Bamossy, 1997; Pavlínek, 2008; Uhlenbruck and de Castro, 2000) and employees (Sharpe, 2001) can be powerful stakeholders and strong influences on MNC-subsidiary relations. Further research should seek to unravel this nexus of internal and external influences around the AMT.

Second, we extrapolated simple bipolar constructs from existing studies to represent the variability of subsidiary identity. While the literature offers a robust starting point, research projects that directly study subsidiary identity are likely to reveal further dimensions of subsidiary identity, from which a less abstract set of conceptual tools can be developed. Third, our theory has been explored in the context of brownfield subsidiaries with contrasting institutional histories, providing particularly propitious conditions for developing a clear theoretical argument. Future research should examine political sensemaking processes in a wider variety of IB circumstances. Supportive evidence from studies of international joint ventures (Inkpen and Beamish, 1997) and institutionally proximate locations (Geppert et al., 2003; Kristensen and Zeitlin, 2005; Vaara, 2003) reinforce expectations that international management and subsidiary integration are essentially politicized phenomena. 
Fourth, while the abstract process of typification through which we have developed our constructs helps initial theory building efforts, it can also lead to over-abstract and over-simple theorizing. Since, as our case references demonstrate, subsidiary integration is unlikely to unfold around simple process patterns, we need to understand more about how complex event sequences are composed over time. Real-time longitudinal studies of MNC-subsidiaries relations would reveal more about the variety of processes within post-acquisition integration, their sequencing and internal dynamics.

A political sensemaking approach is particularly relevant to understanding the MNC as a decentralized and distributed system. As head offices concede hierarchical authority and centralized direction, the overall corporate settlement can only be realized through the political interactions of power holders across the network. Our approach forces theoretical attention on issues of organizational plurality, process and politics. For example, our arguments underscore the importance of recent developments in the literatures on subsidiary autonomy and power and subsidiary initiative, mandates and roles (see e.g. Rugman, Verbeke and Yuan in this issue); they direct scholarly energy beyond mainstream structural and functional logic towards questions about the emergent, socio-political construction of the MNC. As we understand better the social complexity associated with the nexus of local contexts which constitute the modern MNC, we are in a better position to theorize the different paths that MNCs might take towards a stable resolution to the problems associated with dispersed pluralistic organizations. 


\section{References}

Abbott, A. (1990), 'A primer on sequence methods', Organization Science, 1, 375-92.

Albert, S. and Whetten, D. (1985). 'Organizational identity', in Cummings, L.L. and Staw, B.M. (Eds), Research in Organizational Behavior. Greenwich, CT: JAI Press, 263-95.

Bartlett, C.A. and Ghoshal, S. (1989). Managing Across Borders: the Transnational Solution. Boston: Harvard Business School Press.

Becker, P. (1997). 'Das Joint venture zwischen Volkswagen und Skoda: eine erste Bilanz'. Osteuropa-Wirtschaft, 42, 388-417.

Birkinshaw, J.M. (1996). 'How multinational subsidiary mandates are gained and lost'. Journal of International Business Studies, 27, 467-95.

Birkinshaw, J.M., Bresman, H. and Håkanson, L. (2000). 'Managing the post-acquisition integration process: how the human integration and task integration processes interact to foster value creation'. Journal of Management Studies, 37, 395-425.

Birkinshaw, J.M. and Hood, N. (1998). 'Multinational subsidiary evolution: capability and charter change in foreign-owned subsidiary companies'. Academy of Management Review, 23, 773-95.

Birkinshaw, J.M. and Morrison, A.J. (1995). 'Configurations of strategy and structure in subsidiaries of multinational corporations'. Journal of International Business Studies, 26, 72953.

Birkinshaw J. and Ridderstråle, J. (1999). 'Fighting the corporate immune system: a process study of subsidiary initiatives in multinational corporations'. International Business Review, 8, $149-180$.

Bouquet, C. and Birkinshaw J.M. (2008). 'Managing power in the multinational corporation: how low-power actors gain influence.' Journal of Management, 34, 477-508. 
Brouthers, K.D. and Bamossy, G.J. (1997). 'The role of key stakeholders in international joint venture negotiations: case studies from Eastern Europe'. Journal of International Business Studies, 28, 285-308.

Child, J. and Czeglédy, A. (1996). 'Managerial learning in the transformation of Eastern Europe: some key issues'. Organization Studies, 17, 167-80.

Child, J. and Markóczy, L. (1993). 'Host-country managerial behaviour and learning in Chinese and Hungarian joint ventures'. Journal of Management Studies, 30, 611-31.

Clark, E. (2008) 'The post-socialist transformation and global process: knowledge and institution building in organizational settings', in C. Smith, B. McSweeney and R. Fitzgerald (Eds.), Remaking Management: between Global and Local. Cambridge: Cambridge University Press, $127-55$

Clark, E. and Soulsby, A. (1999). Organizational Change in Post-communist Europe: Management and Transformation in the Czech Republic. London: Routledge.

Clegg, S.R., Courpasson, D. and Philips, N. (2006): Power and Organizations. London: Sage. Clemens, E.S. and Cook, J.M. (1999). 'Politics and institutionalism: explaining durability and change.' Annual Review of Sociology, 25, 441-66.

Cohen, W.M. and Levinthal, D.A. (1990). 'Absorptive capacity: a new perspective on learning and innovation'. Administrative Science Quarterly, 35, 128-52.

Cyr, D.J. and Schneider, S.C. (1996). 'Implications for learning: human resource management in East-West joint ventures'. Organization Studies, 17, 207-26.

Czeglédy, A. (1996). 'New directions for organizational learning in Eastern Europe'. Organization Studies, 17, 327-41.

Dobosz-Bourne, D. and Jankowicz, D. (2006). 'Reframing resistance to change: experience from General Motors Poland'. International Journal of Human Resource Management, 17, 2021-34. 
Dörr, G. and Kessel, T. (2002). 'Cooperation and asymmetry: the development profile of an EastWest corporate project'. WZB Working Paper (FSII-02-201), Social Science Research Centre, Berlin.

Doz, Y.L. and Prahalad, C.K. (1991). 'Managing DMNCs: a search for a new paradigm'. Strategic Management Journal, 12, Special Issue, 145-64.

Dutton, J. E. and Dukerich, J.M. (1991). 'Keeping an eye on the mirror: image and identity in organizational adaptation'. Academy of Management Journal, 34, 517-54.

Easterby-Smith, M., Lyles, M.A. and Tsang, E.W.K. (2008). 'Interorganizational knowledge transfer: current themes and future prospects'. Journal of Management Studies, 45, 676-90.

Edwards, V. and Lawrence, P. (2002). Management in Eastern Europe. Basingstoke: Palgrave.

Eisenhardt, K.M. (1989). 'Building theory from case study research'. Academy of Management Review, 12, 532-50.

Ferner, A. and Quintanilla, J. (1998). 'Multinationals, national business systems and HRM: the enduring influence of national identity or a process of "Anglo-Saxonization"”. International Journal of Human Resource Management, 9, 710-30.

Geppert, M. (2003). 'Sensemaking and politics in MNCs: a comparative analysis of vocabularies within the global manufacturing discourse in one industrial sector'. Journal of Management Inquiry, 12, 312-29.

Geppert, M. and Merkens, H. (1999). 'Learning from one's own experience: continuation and organizational change in two East German firms'. Human Resource Development International, 2, 25-40.

Geppert, M., Williams, K. and Matten, D. (2003). 'The social construction of contextual rationalities in MNCs: an Anglo-German comparison of subsidiary choice'. Journal of Management Studies, 40, 617-41.

Ghoshal, S. and Bartlett, C.A. (1990). 'The multinational corporation as an interorganizational network'. Academy of Management Review, 15, 603-25. 
Ghoshal, S. and Bartlett, C.A. (1988). 'Creation, adoption, and diffusion of innovations by subsidiaries of multinational corporations'. Journal of International Business Studies, 19, 36588.

Gioia, D.A. and Chittipeddi, K. (1991). 'Sensemaking and sensegiving in strategic change initiation'. Strategic Management Journal, 12, 433-48.

Gioia, D.A. and Thomas, J.B. (1996). 'Identity, image, and issue interpretation: sensemaking during strategic change in academia'. Administrative Science Quarterly, 41, 370-403.

Glaser, B.G. and Strauss, A.L. (1967). The discovery of grounded theory: strategies for qualitative research. Chicago: Aldine.

Gupta, A.K. and Govindarajan, V. (2002). 'Cultivating a global mindset'. Academy of Management Executive, 16, 116-26.

Hambrick, D.C. and Cannella, A.A (1993). 'Relative standing: a framework for understanding departures of acquired executives'. Academy of Management Journal, 36, 733-62.

Haspeslagh, P.C. and Jemison, D.B. (1991). Managing Acquisitions: Creating Value through Corporate Renewal. New York: Free Press.

Hatch, M. J. and Schultz, M. (2002). 'The dynamics of organizational identity'. Human Relations, 55, 989-1018.

Hedlund, G. (1986). 'The hypermodern MNC - a heterarchy?' Human Resource Management, 25, 9-35.

Hennart, J-F. and Larimo, J. (1998). 'The impact of culture on the strategy of multinational enterprises: does national origin affect ownership decisions?' Journal of International Business Studies, 29, 515-38.

Hirsch, P.M. (1986). 'From ambushes to golden parachutes: corporate takeovers as an instance of cultural framing and institutional integration'. American Journal of Sociology, 91, 800-37.

Hurt, M and Hurt, S. (2005). 'Transfer of managerial practices by French food retailers to operations in Poland'. Academy of Management Executive, 19, 36-49. 
Inkpen, A.C. and Beamish, P.W. (1997). 'Knowledge, bargaining power, and the instability of international joint ventures'. Academy of Management Review, 22, 177-202.

Janovskaia, A. (2008). 'German automotive multinationals in Central Europe: enterprise coalitions for production'. Industry Studies Conference, Boston, MA: Alfred P. Sloan Foundation,

Jarillo, J.C. and Martínez, J.I. (1990). 'Different roles for subsidiaries: the case of multinational corporations in Spain'. Strategic Management Journal, 11, 501-12.

Jeffries, I. (1990). A Guide to Socialist Economies. London: Routledge.

Kornai, J. (1980). Economics of Shortage. Amsterdam: North Holland Publishing.

Kostova, T. (1999). 'Transnational transfer of strategic organizational practices: a contextual perspective'. Academy of Management Review, 24, 308-24.

Kostova, T. and Roth, K. (2002). 'Adoption of an organizational practice by subsidiaries of multinational corporations: institutional and relational effects'. Academy of Management Journal, 45, 215-33.

Kostova, T. and Zaheer, S. (1999). 'Organizational legitimacy under conditions of complexity: the case of the multinational enterprise'. Academy of Management Review, 24, 64-81.

Kostova, T., Roth, K. and Dacin, T. M. (2008). 'Institutional theory in the study of multinational corporations: a critique and new directions'. Academy of Management Review, 33: 994-1006.

Kristensen, P.H. and Zeitlin, J. (2001). 'The making of a global firm: local pathways to multinational enterprise', in Morgan, G., Kristensen, P.H. and Whitley, R. (Eds), The multinational firm: organizing across institutional and national divides. Oxford: Oxford University Press, 172-95.

Kristensen, P.H. and Zeitlin, J. (2005). Local players in global games: the strategic constitution of a multinational corporation. Oxford: Oxford University Press.

Lewin, A.Y., Long, C.P. and Carroll, T.N. (1999). 'The coevolution of new organizational forms'. Organization Science, 10, 535-50. 
Maitlis, S. and Sonenshein, S. (2010). 'Sensemaking in crisis and change: inspiration and insights from Weick (1988)'. Journal of Management Studies, 47, 551-80.

Meyer, K.E. (2000). 'International production networks and enterprise transformation in Central Europe'. Comparative Economic Studies, 42, 135-50.

Meyer, K.E. and Lieb-Dóczy, E. (2003). 'Post-acquisition restructuring as evolutionary process'. Journal of Management Studies, 40, 459-82.

Meyer, K., Mudambi, R. and Narula, R. (2010). 'Multinational enterprises and local contexts: the opportunities and challenges of multiple-embeddedness'. Journal of Management Studies, this issue.

Michailova, S. and Husted, K. (2003). 'Knowledge sharing hostility in Russian firms'. California Management Review, 45, 59-77.

Morgan, G. and Kristensen, P.H. (2006). 'The contested space of multinational; varieties of institutionalism: varieties of capitalism'. Human Relations, 59, 1467-90.

Mudambi, R. and Navarra, P. (2004). 'Is knowledge power? Knowledge flows, subsidiary power and rent-seeking within MNCs'. Journal of International Business Studies, 35, 385-406.

Nahavandi, A. and Malekzadeh, A.R. (1988). 'Acculturation in mergers and acquisitions'. Academy of Management Review, 13, 79-90.

Newman, K. (2000). 'Organizational transformation during institutional upheaval'. Academy of Management Review, 25, 602-19.

Nooteboom, B. (2000). Learning and Innovation in Organizations and Economies. Oxford: Oxford University Press.

Pavlínek, P. (2002). 'The role of foreign direct investment in the privatisation and restructuring of the Czech motor industry'. Post-Communist Economies, 14, 359-79.

Pavlínek, P. (2008). A Successful Transformation? Restructuring of the Czech Automobile Industry. New York: Springer. 
Peng, M.W. (2003). 'Institutional transitions and strategic choices'. Academy of Management Review, 28, 275-96.

Perlmutter, H. (1969). 'The tortuous evolution of the MNC'. Columbia Journal of World Business, 4, 9-18.

Pratt, M.G. and Foreman, P.O. (2000). 'Classifying managerial responses to multiple organizational identities'. Academy of Management Review, 25, 18-42.

Rosenzweig, P.M. and Nohria, N. (1994). 'Influences on human resource management practices in multinational corporations'. Journal of International Business Studies, 25, 229-51.

Roth, K. and Morrison, A.J. (1990). 'An empirical analysis of the integration-responsiveness framework in global industries'. Journal of International Business Studies' 21' 541-64.

Rugman, A., Verbeke, A. and Yuan, W. (2010). 'Reconceptualizing Bartlett and Ghoshal's classification of national subsidiary roles in the multinational enterprise'. Journal of Management Studies, this issue.

Schütz, A. (1972). The Phenomenology of the Social World. London: Heinemann.

Scott, S.G. and Lane, V.R. (2000). 'A stakeholder approach to organizational identity'. Academy of Management Review, 25, 43-62.

Sharpe, D.R. (2001). 'Globalization and change: organizational continuity and change within a Japanese multinational in the UK', in Morgan, G., Kristensen, P.H. and Whitley, R. (Eds), The Multinational Firm: Organizing Across Institutional and National Divides. Oxford: Oxford University Press, 196-221.

Simon, L. and Davies, G. (1996). 'A contextual approach to management learning: the Hungarian case'. Organization Studies, 17, 269-89.

Soulsby, A. and Clark, E. (1996). 'The emergence of post-communist management in the Czech Republic'. Organization Studies, 17, 227-47. 
Soulsby, A and Clark, E. (2007). 'Organization theory and the post-socialist transformation: contributions to organizational knowledge. Human Relations, 60, 1419-42.

Stark, D. (1996). 'Recombinant property in East European capitalism'. American Journal of Sociology, 101, 993-1027.

Taggart, J. and Hood, N. (1999): 'Determinants of autonomy in multinational corporation subsidiaries'. European Management Journal, 17, 226-236.

Uhlenbruck, K. and de Castro, J.O. (2000). 'Foreign acquisitions in central and Eastern Europe: outcomes of privatization in transitional economies'. Academy of Management Journal, 43, $381-402$.

Uhlenbruck, K., Meyer, K.E. and Hitt, M.A. (2003). 'Organizational transformation in transition economies: resource-based and organizational learning perspectives'. Journal of Management Studies, 40, 257-82.

Vaara, E. (2000). 'Constructions of cultural differences in post-merger change processes: a sensemaking perspective on Finnish-Swedish cases’.M@n@gement, 3, 81-110.

Vaara, E. (2003). 'Post-acquisition integration as sensemaking: glimpses of ambiguity, confusion, hypocrisy, and politicization'. Journal of Management Studies, 40, 859-94.

Van de Ven, A.H. and Poole, M.S. (1995). 'Explaining development and change in organizations'. Academy of Management Review, 20, 510-40.

Watkins, J.W.N. (1952). 'Ideal types and historical explanation'. British Journal for the Philosophy of Science. 3, 22-43.

Weick, K.E. (1995). Sensemaking in Organizations. London: Sage.

White, R.E. and Poynter, T.A. (1984). 'Strategies for foreign-owned subsidiaries in Canada'. Business Quarterly, 49, 59-69.

Yin, R. (2003). Case Study Research (3rd Edition). Thousand Oaks, CA: Sage. 
Table I

Head Office Management Subsidiary Identities

\begin{tabular}{|c|c|c|}
\hline & Strategic dependant & Strategic partner \\
\hline Strategic mindset & Ethnocentric; unicultural & Polycentric; multi-cultural \\
\hline Strategic mandate & Non-creative & Creative \\
\hline Interests & Change subsidiary to fit MNC & $\begin{array}{l}\text { Encourage subsidiary to develop } \\
\text { within MNC }\end{array}$ \\
\hline Political stance & Domination, unilateral power & $\begin{array}{l}\text { Negotiation, seek mutual } \\
\text { agreement }\end{array}$ \\
\hline
\end{tabular}

Table II

Post-socialist Management Subsidiary Identities

\begin{tabular}{|c|c|c|}
\hline & Local patriot & Cosmopolitan player \\
\hline $\begin{array}{r}\text { Focus of } \\
\text { embeddedness }\end{array}$ & Locally embedded & Globally connected \\
\hline $\begin{array}{r}\text { Openness to } \\
\text { management ideas }\end{array}$ & $\begin{array}{l}\text { Low absorptive capacity, self- } \\
\text { reliance }\end{array}$ & High absorptive capacity \\
\hline Interests & $\begin{array}{l}\text { Develop site from within; sustain } \\
\text { local networks }\end{array}$ & $\begin{array}{l}\text { Encourage foreign cooperation; } \\
\text { develop corporate career }\end{array}$ \\
\hline Political stance & $\begin{array}{l}\text { Defence, from opposition to } \\
\text { passive resistance }\end{array}$ & $\begin{array}{l}\text { Acceptance, from internalization } \\
\text { to expedience }\end{array}$ \\
\hline
\end{tabular}

Table III

Reconstruction of Subsidiary Identity and Institutions: Process Patterns

\begin{tabular}{|c|c|c|c|c|}
\hline & Accumulating & Adaptive & Non-adaptive & Deteriorating \\
\hline $\begin{array}{l}\text { Scenario } \\
\text { sequence }\end{array}$ & $1 \rightarrow 1 \rightarrow 1$ & $2 \& 3 \rightarrow 1$ & $2 \& 3 \rightarrow 4$ & $4 \rightarrow$ exit \\
\hline $\begin{array}{l}\text { Central } \\
\text { process feature }\end{array}$ & Stability & $\begin{array}{l}\text { Increasing } \\
\text { stability }\end{array}$ & $\begin{array}{l}\text { Increasing } \\
\text { instability }\end{array}$ & Crisis \\
\hline Identities & Congruent & $\begin{array}{l}\text { Increasing } \\
\text { congruence }\end{array}$ & $\begin{array}{c}\text { Increasing } \\
\text { incongruence }\end{array}$ & Contradictory \\
\hline $\begin{array}{l}\text { Political } \\
\text { sensemaking }\end{array}$ & Consensual & $\begin{array}{l}\text { Decreasing } \\
\text { contestation }\end{array}$ & $\begin{array}{l}\text { Increasing } \\
\text { contestation }\end{array}$ & Oppositional \\
\hline $\begin{array}{l}\text { Generative } \\
\text { mechanism }\end{array}$ & $\begin{array}{l}\text { Perceived } \\
\text { consonance }\end{array}$ & $\begin{array}{c}\text { Perceived } \\
\text { discrepancy } \rightarrow \\
\text { conciliation }\end{array}$ & $\begin{array}{c}\text { Perceived } \\
\text { discrepancy } \rightarrow \\
\text { aggravation }\end{array}$ & $\begin{array}{c}\text { Perceived } \\
\text { contradiction }\end{array}$ \\
\hline $\begin{array}{l}\text { Institution } \\
\text { building } \\
\text { outcomes }\end{array}$ & $\begin{array}{l}\text { Deep } \\
\text { restructuring; } \\
\text { strategic } \\
\text { autonomy }\end{array}$ & $\begin{array}{l}\text { Increasing depth } \\
\text { and strategic } \\
\text { autonomy }\end{array}$ & $\begin{array}{l}\text { Decreasing depth } \\
\text { and strategic } \\
\text { autonomy }\end{array}$ & $\begin{array}{l}\text { None: structural } \\
\text { and strategic } \\
\text { chaos }\end{array}$ \\
\hline
\end{tabular}


Figure 1: Post-Acquisition Integration as Political Sensemaking Process

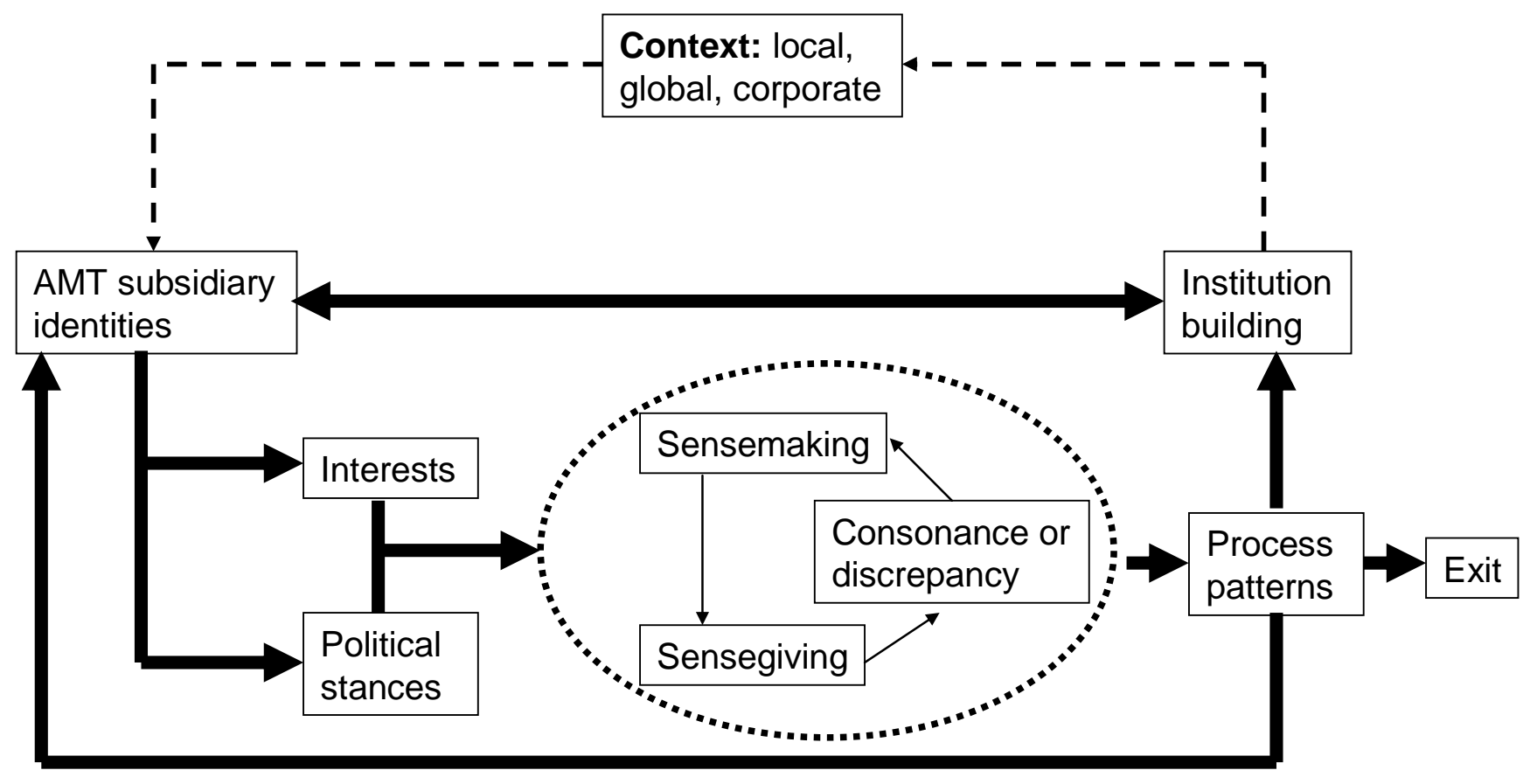


Figure 2: Political Sensemaking and Process Patterns

\begin{tabular}{|c|c|c|}
\hline \multirow{2}{*}{$\begin{array}{l}\text { Post-socialist } \\
\text { subsidiary } \\
\text { identities }\end{array}$} & \multicolumn{2}{|c|}{ Head office subsidiary identities } \\
\hline & Strategic partner & Strategic dependant \\
\hline $\begin{array}{l}\text { Cosmopolitan } \\
\text { player }\end{array}$ & $\begin{array}{l}\text { 1. CONSENSUAL } \\
\text { SENSEMAKING } \\
\rightarrow \quad \begin{array}{l}\text { Internalized adoption } \\
\text { and deep restructuring }\end{array}\end{array}$ & $\begin{array}{l}\text { 3. DOMINATED } \\
\text { SENSEMAKING } \\
\text { Ceremonial adoption and } \\
\text { shallow restructuring }\end{array}$ \\
\hline Local patriot & $\begin{array}{l}\text { 2. DEFENSIVE } \\
\text { SENSEMAKING } \\
\mathbf{l} \text { Ceremonial adoption } \\
\text { and shallow restructuring }\end{array}$ & $\begin{array}{l}\text { 4. OPPOSITIONAL } \\
\text { SENSEMAKING \|e } \\
\text { Contested adoption } \\
\text { and institutional crisis }\end{array}$ \\
\hline
\end{tabular}

